\title{
Microfinance Institutions Fostering Sustainable Development by Region
}

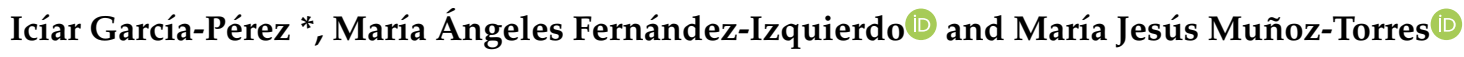 \\ Department of Finance and Accounting, Law and Economics Faculty, Jaume I University, Campus del Riu Sec, \\ 12071 Castellón, Spain; afernand@uji.es (M.Á.F.-I.); munoz@uji.es (M.J.M.-T.) \\ * Correspondence: icgarcia@uji.es
}

Received: 18 February 2020; Accepted: 25 March 2020; Published: 29 March 2020

check for updates

\begin{abstract}
In the last few years, considerable attention has been paid to microfinance as a relevant participant in the formal financial system, whose target audience is people who are otherwise at risk of financial exclusion. In parallel, sustainability and the promotion of Sustainable Development (SD) are imposed as the theoretical frame when facing any study. This, connected with cultural and organizational dimensions theories, are the analytical framework for the analysis of the relationship between the context of performance in which Microfinance Institutions (MFIs) operate and their activity in promoting sustainability. A holistic approach is necessary to make operational these concepts; for that reason, financial, environmental, social and governance dimensions (FESG), and the balance among them, have to be considered. The main objective of the paper is to explore to what extent MFIs are fostering SD, and how this promotion is performed by region. For the analysis, two different sources of information have been studied: sectoral academic literature that focuses on the different sustainability dimensions, and MIX Market sustainability data obtained from the MFIs. A keyword analysis of the selected papers has been executed to be conscious of the most investigated aspects by region; on the data provided by the institutions, a Kruskal-Wallis $\mathrm{H}$ test has been performed to learn what the main Sustainability Indicators (SIs) are that are reported affirmatively. To obtain comprehensive research, a comparative study of the results offers the convergences, divergences and gaps of information in each of the regions. The findings show significant differences depending on the region, and confirm that operationalization should be adjusted at the regional context of the MFIs. The paper, with the inherent limitations due to data quality, also offers recommendations for the better promotion of sustainability in each of the regions.
\end{abstract}

Keywords: microfinance; microfinance institutions; sustainability; FESG; region

\section{Introduction}

The microfinance system offers financial services worldwide, especially in emerging markets, to a population with limited access to the conventional financial market or at risk of financial exclusion. The sector is characterized by focusing on low-money products and services, with easy access financial instruments, simple opening processes and with regulated return guarantees. Low-income clients seek microfinance to attend to solving basic needs, personal emergencies or the expansion of a small business, among others. This lending business that is constantly growing, presented in 2018 around 916 Microfinance Institutions (MFIs), with an estimated USD 124 billion gross loan portfolio, and resulting in 140 million active borrowers worldwide, where $80 \%$ are women and $65 \%$ are rural borrowers [1]. According to the Microfinance Barometer 2019, the Latin America and Caribbean (LAC) region presents the highest number of MFIs ( 248 institutions) and the largest credit portfolio ( 48.3 billion). Regarding the number of clients, South Asia has almost $70 \%$ of the total clients, in which $89 \%$ of them are women. The regions with the highest percentage of rural clients are East Asia and Pacific (EAP) and South 
Asia (79\% and 72\% respectively). Eastern Europe and Central Asia (EECA) and Middle East and North Africa (MENA) are the regions where microfinance presence is lowest in terms of the number of institutions, credit portfolio size and clients served.

The main goal of the microfinance sector and its MFIs is to financially empower the poorest members of society and to foster Sustainable Development (SD) [2-4] through their operations. SD is "the development that meets the needs of the present without compromising the ability of future generations to meet their own needs" [5]. That is, SD integrates the commitment of societal evolution toward a more equitable and wealthy world for generations to come [4]. Practitioners and academics have addressed SD from different perspectives, assuming that it is a great challenge to conceptualize and operationalize SD, due to the complexity and variety of factors involved. From a micro-level approach, SD is promoted through organizational sustainability that entails an equilibrium among the financial, social, environmental and governance (FESG) performance dimensions $[4,6,7]$ in the short and long term [8].

Globally, poverty is distributed unevenly. Data provided by the World Bank (2018) indicate that 736 million people worldwide are living below the international poverty line and are located mainly in Sub-Saharan Africa (41\%), South Asia (12\%) and in MENA (5\%). In addition, extreme poverty is overwhelmingly rural, where the poverty rate in rural areas is more than three times greater than in urban areas. Deepening into the multidimensionality of poverty and SD, monetary deprivation is detected mainly in Sub-Saharan Africa, while educational privation is remarkable in South Asia, and the LAC, and EAP and MENA regions have a high lack of basic infrastructure. Therefore, considering that microfinance can usefully link up with SD [1], in order to achieve the eradication of poverty and satisfactorily foster SD, it is necessary to consider its multidimensionality in which the FESG dimensions are integrated, and acknowledge the need for equitable SD in certain regions or countries [9].

Elaborating on this, on the one hand, previous studies on microfinance have considered different areas of performance, but they have been assessed mainly from an economic and socio-economic perspective [10] with results that have not always reached a consensus [11-13]. However, to the authors' best knowledge, microfinance institutions' performance has been scarcely explored from a holistic approach, considering an integrative sustainability framework.

On the other hand, the MIX Market Financial Performance Report (2017) [14] presents a global positive sector trend with regional variations, thus, regional differences play an important role in the fine-grain analysis [15]. Previous microfinance research shows the need for an in-depth analysis considering the importance of region-specific parameters [16-18].

Moreover, as far as the researchers are aware, microfinance has been scarcely investigated from the point of view of sustainability or its impact on sustainable development, where the contexts of the regions should be considered. For this reason, the purpose of this study is to explore to what extent microfinance institutions are fostering SD differently depending on the geographical area, and why.

For addressing this research topic, two complementary sources of information were considered; microfinance-specific academic literature, which provides accurate and deep knowledge about the microfinance system and its institutions, and the MIX Market database that integrates information of a FESG nature about the MFIs on an institution-by-institution basis. The analysis of these data will allow us to answer the following questions:

- Which are the main aspects related to MFI sustainability, researched by region?

- Which are the main Sustainability Indicators (SIs) reported by the MFIs worldwide?

- Which are the differences between regions on SI reporting?

- Which are the most important links and gaps between the main aspects reported by MFIs, and the main aspects studied by region?

The objective is to build on these gaps and provide insightful information to help to characterize the microfinance sector at the regional level. 
The remainder of the paper is organized as follows: Section 2 contains the academic background, Section 3 describes the research design, data collection and data analysis methods applied. Findings are shown in Section 4. Finally, Section 5 includes the discussion and conclusions.

\section{Literature Review}

The present study is based on the sustainability theoretical framework and the relationship between the cross-national cultural dimensions and organizational cultural dimensions theories developed by Hofstede $[13,17]$, for the investigation of the relationship between the context of performance in which MFIs operate and their activity in promoting sustainability.

Since the early eighties, microfinance has been providing financial access to people and small businesses that, until that time, could not participate in the formal financial system. Through different services such as microcredit, micro-insurance, micro-savings and money transfers [11,19], this sector aims to reach out to the poorest population to become self-sufficient [20], while they consolidate as financial institutions that are economically sustainable in the long term. According to the literature, some of the main aspects that characterize the microfinance institutions are their financial structure, the important role of the foreign donors [4], the heterogeneity of the MFIs-with respect to size, location and legal status [19]—and their specific risk control mechanisms [12].

$\mathrm{SD}$ is a multifaceted concept that comprises social and economic prosperity without contravening planetary boundaries [21-23]. It is, therefore, that the present socio-economic evolution is bound to the commitment of the welfare of future generations [24]. From a holistic perspective, sustainability is understood as a balance between the financial, social, environmental and governance dimensions $[4,6,7]$, highlighting the importance of the interrelation and equilibrium among the four dimensions in the short and long-term [8].

Much research on microfinance has been done under the FESG principles, where analyses of a financial and social nature have been predominant in the literature [10]. More recent studies focus on environmental and governance aspects, and the interrelation with the other two sustainability dimensions. It includes, for example, studying the social-environmental links among microfinance, gender equity and the environment [25], including the environment as a commitment into the structure of their financial products [18], relating governance and financial performance [26-28], and analyzing the regulatory changes needed to implement successful microfinance in the pursuit of SD [29,30], among others. However, until recently, not many authors had analyzed this financial system and its institutions with a sustainability and holistic approach [2-4].

Moreover, the results of studies on the efficiency of MFIs do not reach a consensus on the effects of microfinance on poverty, financial inclusion, improvements on household conditions or gender equality [11-13], among others. In addition to this, inequalities arise when studying the effects by region. Meanwhile, in regions such as South Asia and EAP, microfinance is presented as relatively valuable, whereas in other regions such as Africa, it seems to accentuate the problem [31,32].

Finding an explanation for these differences is complex given the multiple factors that affect it. Local context determines a wide variety of aspects such as market and infrastructure constraints [33,34], cyclical income [35], variations in health services [36], power relationships [37,38] or the specific needs of institution models [17,39].

Several microfinance studies have considered, directly or indirectly, the cultural dimensions theory of Hofstede (1980) [15]. This theoretical framework defines the impact of cross-national values on the behavior of society. For Hofstede [13], culture is a collective mental programming that influences patterns of thinking and differentiates groups of people. The fact that the individual is affected by a strong social influence makes it possible to compare large groups. The cultural dimensions used for the characterization and subsequent comparison of national culture are (1) individualism vs. collectivism, (2) masculinity vs. femininity, (3) uncertainty avoidance, (4) power distance and (5) long-term vs. short-term orientation. Then, the authors will approach the academic literature on microfinance based on Hofstede's model, connecting it to the FESG principles. 
(1) When considering the individualistic-collectivistic dimension, microfinance research establishes a positive relationship in those societies more collectivist $[40,41]$ and with higher levels of trust $[41,42]$. These circumstances are directly related to financial facts like considering self-help groups when granting funding, and in turn derived from social issues such as possible access to health services $[43,44]$ or the consequences of this kind of repayment model, especially in the case of women $[45,46]$. This statement is contrasted to some extent with the individualism required for the entrepreneurship that seeks to promote microfinance. Thus, some authors suggest a change of policies to attend to this profile that incentivizes the involvement of the husband in the microenterprises run by women [47], tailor-made financing products and services according to the specific target, and investment in training and technical assistance that facilitates entrepreneurship [48].

(2) The masculinity-femininity cultural dimension is also relevant; in this case, financial and social aspects emerge in studies that conclude that the cultural factors that influence the women's experience should be analyzed and understood to establish the link between microfinance and gender inequality $[45,49,50]$, intimate partner violence prevention [51] or access to health care [44].

(3) The uncertainty avoidance dimension - that is, the regulation, controls and laws society needs to mitigate insecurity and ambiguity -in microfinance, become economic and governance consequences. Microfinance scholarly literature notes a reduction of the loan loss interest rates in countries where the MFIs' financial performance is reported, where the institution is registered and follows regulations or laws [10], and where microfinance is an agricultural supporter [12] through products such as weather index-based insurance associated with agricultural lending to mitigate credit risk due to adverse situations [13].

(4) The power distance cultural dimension indicates to what extent particular societies question or accept authority, and how strong the social hierarchy is. These will have financial and governance consequences and determine how microfinance activity should be managed. As shown in [52], it indicates that in rural Bangladesh, strict supervision over customers is needed to ensure that the funding received goes to productive programs [12], and that it should be considered how the hierarchical structure of an MFI should be designed to prevent it from being prone to corruption [13]. Cultures that value severe hierarchy are unlikely to have an entrepreneurial spirit [14]; therefore, it will have an adverse effect on the demand for financing products.

(5) Time perspective orientation considers how inclined a society is to plan the future, or whether or not it tends to be present-oriented. Sustainability has a long-term orientation [8], while microfinance products tend to be designed for the short term. This means that microfinance, as is, cannot meet the needs of self-employed businesses seeking stable financing [12], and thus weakens longer-term adaptive capacity $[13,14]$. An important aspect connecting this cultural dimension with the FESG framework is the environment. Authors encouraging environmental behaviors link microfinance to long-term development, for its relation to gender equality [15] and to prevent the paradox of financing activities that endanger the health and livelihood of the receivers [16].

Hofstede's cultural dimensions show how national and regional cultures influence society's habits and behaviors. Likewise, the consequences of cultural differences have an impact on the functioning of institutions [39,40,53]. Therefore, as Hofstede (2001) [54] notes, at the organizational level, the management of any institution requires a cultural understanding of society and of the organization itself.

As in the FESG dimensions, there is a strong interrelation among Hofstede's cultural dimensions. Likewise, each of the cultural dimensions finds its repercussions in the different FESG areas. Therefore, Hofstede's theory reinforces the need to consider the activity of MFIs from the point of view of sustainability, considering the financial, social, environmental and governance dimensions, as well as considering the organizational differences that may arise from the different regional parameters. Organizational cultural dimensions strengthen the need to consider the study of microfinance 
organizations from a sustainability approach and to consider their specificities to detect and analyze whether the sustainability performance of the MFIs is different depending on the geographic area, and why.

To do that, this research examines to what extent MFIs are contributing to sustainable development in the different areas of the world, based on academic literature and voluntary information provided by the individual MFIs, and explores the reasons and consequences.

\section{Methods}

\subsection{Research Design}

The research design is based on the collection of data from two sources. These are firstly, articles on microfinance in which regional aspects are taken into account, and secondly, the MIX Market database in which institutions worldwide, grouped by regions, report on aspects related to sustainability.

In the case of microfinance-related articles, the analysis was carried out based on the selection of specific keywords. In the case of the MIX Market, the different SIs present in the database have been analyzed; see Figure 1. In both cases, the analysis considers the region as a key element for the study.

Once the data have been obtained from each of the information sources, coincidences and divergences in the different aspects and features were analyzed, as well as the research gaps in each source, individually and jointly, for each of the regions.

\subsection{Data Collection and Analysis}

\subsubsection{Paper Data Collection and Analysis of Keywords}

For the review of the microfinance sectoral literature, The Web of Science database was chosen as a multidisciplinary, rigorous and reliable resource for the research $[55,56]$.

From a methodological standpoint, content analysis has been implemented [57,58], as it considers quantitative and qualitative methods to make inferences [59]. For this, the selection of articles is explored with an inductive approach without previous assumptions [60], where the broad term microfinance has been entered into the Thomson Reuters' Web of Science search engine $[55,61]$. Then, to refine the sample, in addition to the term microfinance in the title, the article selected refers in the title or the keywords [62,63] to a geographic location (city, country, continent or region). That is, each of the articles selected for the analysis contains the term microfinance in the title and deals with a geographical context defined in the title or the keywords.

Once the sample is completed, articles are divided by region for their analysis. The regions defined are Africa, East Asia and The Pacific (EAP), Eastern Europe and Central Asia (EECA), Latin America and The Caribbean (LAC), Middle East and North Africa (MENA), North America, Oceania, South Asia, and Western Europe. These regions correspond to those used by the MIX Market database and are those that are traditionally used in microfinance $[10,27,64]$.

In the content, the analysis method is essential to design a method for the systematic and objective identification of specific categories $[59,60]$ that allows the assignment of each unit of analysis to a particular dimension under specific selection criteria [65]. Category definitions are based on the Global Reporting Initiative (GRI) Sustainability Reporting Guidelines, as they are considered to be a standardized sustainability reporting frame, and their structure organizes FESG issues in a normalized disclosure. 


\begin{tabular}{|c|c|c|c|}
\hline FESG dimension & Category & Sustainability Indicator description & Code \\
\hline \multirow{16}{*}{$\begin{array}{c}\text { FINANCIAL- } \\
\text { ECONOMIC } \\
\text { (PRODUCTS \& } \\
\text { SERVICES) }\end{array}$} & \multirow{4}{*}{$\begin{array}{c}\text { INCOME } \\
\text { GENERATING LOANS }\end{array}$} & Microenterprise loans & $\mathrm{FC} 1$ \\
\hline & & SME loans & $\mathrm{FC} 2$ \\
\hline & & Agricultural/livestock loans & FC3 \\
\hline & & Express loans & FC4 \\
\hline & \multirow{4}{*}{$\begin{array}{l}\text { NON-INCOME } \\
\text { GENERATING LOANS }\end{array}$} & Education loans & FC5 \\
\hline & & Emergency loans & FC6 \\
\hline & & Housing loans & FC7 \\
\hline & & Loans for other household needs/consumption & FC8 \\
\hline & \multirow{4}{*}{ SAVINGS } & Compulsory savings accounts & FC9 \\
\hline & & Voluntary savings accounts & FC10 \\
\hline & & Compulsory insurance & FC11 \\
\hline & & Voluntary insurance & FC12 \\
\hline & \multirow{4}{*}{ SERVICES } & Offers other financial services & FC13 \\
\hline & & Enterprise services (nonfinancial) & FC14 \\
\hline & & Other education services (nonfinancial) & FC15 \\
\hline & & Health services (nonfinancial) & FC16 \\
\hline \multirow{4}{*}{ ENVIRONMENT } & \multirow{4}{*}{$\begin{array}{l}\text { SPECIFIC ACTIONS \& } \\
\text { EVALUATION }\end{array}$} & $\begin{array}{l}\text { The institution conducts activities related to raising awareness of } \\
\text { environmental impacts, such as: running training sessions and } \\
\text { discussions, displaying posters, distributing flyers, etc. } \\
\end{array}$ & EN1 \\
\hline & & $\begin{array}{l}\text { The institution includes clauses in loan contracts that require clients to } \\
\text { improve environmental practices/mitigate environmental risks. }\end{array}$ & EN2 \\
\hline & & $\begin{array}{l}\text { The institution uses specific tools to evaluate the environmental risks of } \\
\text { clients' activities (categorizing client risk levels by sector, surveying } \\
\text { environmental impacts, use of an exclusion list, etc.) }\end{array}$ & EN3 \\
\hline & & \begin{tabular}{|l|}
$\begin{array}{l}\text { The institution offers specific loans linked to environmentally friendly } \\
\text { products and/or practices. }\end{array}$ \\
\end{tabular} & EN4 \\
\hline & \multirow{3}{*}{ POVERTY TARGETS } & Very poor clients & $\mathrm{SC} 1$ \\
\hline & & Social goals $>$ Poverty targets $>$ Poor clients & $\mathrm{SC} 2$ \\
\hline & & Social goals $>$ Poverty targets $>$ Low income clients & SC3 \\
\hline & \multirow{3}{*}{ TARGET MARKET } & Women & $\mathrm{SC} 4$ \\
\hline & & Adolescents and youth (below 18) & $\mathrm{SC} 5$ \\
\hline & & Clients living in rural/urban areas & SC6 \\
\hline & MEASUREMENT & Measures client poverty & SC7 \\
\hline & \multirow{12}{*}{$\begin{array}{l}\text { DEVELOPMENT } \\
\text { GOALS }\end{array}$} & Increased access to financial services & $\mathrm{SC} 8$ \\
\hline & & Poverty reduction & SC9 \\
\hline & & Employment generation & SC10 \\
\hline & & Development of start-up enterprises & SC11 \\
\hline & & Growth of existing businesses & $\mathrm{SC} 12$ \\
\hline & & Improvement of adult education & $\mathrm{SC} 13$ \\
\hline & & Youth opportunities & SC14 \\
\hline & & Children's schooling & $\mathrm{SC} 15$ \\
\hline & & Health improvement & SC16 \\
\hline & & Gender equality and women's empowerment & SC17 \\
\hline & & Access to water and sanitation & SC18 \\
\hline & & Housing & SC19 \\
\hline & \multirow{7}{*}{ CLIENT PROTECTION } & Robust repayment evaluation & $\mathrm{SC} 20$ \\
\hline & & Internal audits verify over-indebtedness prevention & $\mathrm{SC} 21$ \\
\hline & & Full disclosure of prices, terms, and conditions & $\mathrm{SC} 22$ \\
\hline & & Clear debt collection practices & SC23 \\
\hline & & Functioning client complaint mechanism & $\mathrm{SC} 24$ \\
\hline & & Privacy data clause in loan contracts & SC25 \\
\hline & & Interest rate calculation method: Declining balance interest method & SC26 \\
\hline \multirow{10}{*}{ GOVERNANCE } & \multirow{3}{*}{ BOARD } & Board orientation on social mission and goals & GV1 \\
\hline & & SPM champion and/or SPM committee on board & GV2 \\
\hline & & Board member with SP education and/or work experience & GV3 \\
\hline & \multirow{2}{*}{$\begin{array}{l}\text { BASES FOR STAFF } \\
\text { INCENTIVES } \\
\end{array}$} & Quality of social data collection & GV4 \\
\hline & & Portfolio quality & GV5 \\
\hline & \multirow{5}{*}{$\begin{array}{l}\text { HUMAN RESOURCE } \\
\text { POLICIES }\end{array}$} & Social protection (medical insurance and/or pension contribution) & GV6 \\
\hline & & Safety policy & GV7 \\
\hline & & Anti-harassment policy & GV8 \\
\hline & & Non-discrimination policy & GV9 \\
\hline & & Grievance resolution policy & GV10 \\
\hline
\end{tabular}

Figure 1. Sustainability indicators (SIs) classified by financial, environmental, social and governance (FESG) dimension and category. (Source: authors.) 
These different sections defined by the GRI will be the categories in which the units of analysis will be assigned; in this case, the keywords. The financial category includes economic performance, economic impacts or market presence. The environmental category accounts for emissions, resource use and environmental grievance mechanisms. The social category presents human rights, labor practices and health conditions, among others. The governance category contains information about the board characteristics, the governance structure and the mechanisms of corporate governance. That is, to determine which sustainability approach is given in the various articles, each of the keywords has been categorized and classified according to the GRI standardized reference framework [66].

Keywords have been treated as written in the papers; nevertheless, some qualitative normalization of the keywords database has been performed, unifying the plural and the singular, grouping synonyms or joining abbreviations relating to their expressions.

The coding consists of a transformation using the precise rules of the raw data of the text [55]; besides, the intersubjective coding of data in the content analysis must be verifiable and reliable [56]. For this, as indicated by [57], to ensure reliability in categorization, they require that at least two coders independently describe a possibly broad set of register units in terms of a common language. Reliability is expressed as a function of the agreement. If the agreement is unanimous for all units, reliability is guaranteed. Previous works have applied the following method for a systematic categorization of terms $[10,67,68]$ : the process involves two academic experts in the sustainability and microfinance fields that review every keyword and assign each term to one of the four GRI categories. If different interpretations can be made of a specific keyword, the title and abstract of the article are used for the contextualization and following assignment, considering that any content analysis should be done concerning the context of the data and justified based on it [57]. In case of any discrepancy in the classification of a word, a third expert reviews the term. A systematic review of the literature in the field of microfinance has been carried out, coding and categorizing its content under the structure of a standardized framework and following the criteria that ensure its reliability.

\subsubsection{Market Data Collection and Analysis of SIs}

Following previous studies, the analysis is based on the MIX Market database $[10,27,58]$. MIX Market is a data provider that has been collecting, analyzing, and reporting for more than 15 years, specializing in microfinance. To date, this platform contains the best worldwide publicly available data [27] about microfinance FESG performance. The first selection criterium is that the institutions studied must have information of a FESG nature.

The MIX Market database provides SIs for the four different sustainability dimensions. For the selection of the SIs, the academic literature on microfinance FESG evaluation has firstly been considered, so that it can be directly related to different principles and standards, as well as adjusted with GRI guidelines. To categorize and classify the SIs (see Figure 1), a code was assigned to each indicator and is organized according to the FESG dimension to which it corresponds. Figure 1 writes in detail, in each of the dimensions the related indicators present in the MIX Market database. These indicators are reported voluntarily by the MFIs and take a value of 1 if the answer is yes, and 0 otherwise. The selection of indicators analyzed is conditioned to a minimum level of response rate, greater than $15 \%$.

Once the MFI population is filtered, an acceptable level of disclosure quality is mandatory. Data quality is assured by The MIX Market database diamond rating; a higher number of diamonds means a more transparent MFI and more reliable data. This rating grade runs from one to five, where five indicates the highest disclosure standard and transparency (see http://www.themix.org). For a more reliable data selection, and in order to increase the quality level of the results $[28,59]$, the minimum diamond rank considered in this research is three.

As a preliminary step, a univariate analysis of the sample and the SIs was conducted. This technique is commonly used in studies where the objective is to assess the overall status of the microfinance sector or assess it at a specific financial, social, environmental or governance level $[12,26,60,61]$. 
It is necessary to identify if the indicators follow a similar distribution by region; for that purpose, a nonparametric test has been carried out to determine if there are statically significant differences between two or more groups [62] of an independent variable on continuous or ordinal dependent variables. For the Kruskal-Wallis H-test, the program used was the IBM SPSS Statistics v.22.0 software package (IBM Corp., Armonk, NY, USA). Previous studies in microfinance have used this method to analyze populations with heterogeneous variances and/or non-Normal distributions $[4,63,64]$.

A double-entry table reproduces, by region, the percentage of institutions that contemplate each of the indicators. The color code shows the higher or lower frequency of the different actions [10].

\subsubsection{Combined Resources Data Analysis}

A comparative descriptive study of the samples has been performed to determine what the main source of information by region is. To ascertain the complete knowledge by region, from the two sources of information, a double-entry table has been created. This table relates those topics present in the academic literature with the information reported by the institutions [10,65]. In this way, a complete study about the convergences, divergences and information gaps for each of the regions is obtained.

\section{Findings}

\subsection{Findings From the Papers}

From 1993 to February 2020, after eliminating duplicated articles, the result was 966 papers that contain the term microfinance in the title. After applying the selection criteria, the number of articles was 478 . Almost half of the articles (49.5\% of the total) introduce some nature of the location in the topic-that is, in the title, keywords or abstract.

The importance of geographic location is observed when investigating microfinance, confirming that almost half of the number of articles investigating microfinance refer to geographic location.

Table 1 shows the number of articles by region. More than half of the investigations have South Asia and Africa as regions of interest, followed by LAC and EAP, and to a lesser extent, EECA. Fourteen articles deal with two or more regions: a small number that indicates the tendency to focus on a single region for analysis. Regions such as Western Europe, MENA, North America and Oceania have been excluded from our study because they have a reduced critical mass to analyze.

Table 1. Counts by region of the number of scientific articles, and percentages of the total. (Source: authors, based on the Web of Science database).

\begin{tabular}{|l|r|r|}
\multicolumn{1}{c}{ Region } & Number of papers & \% of papers \\
\hline South Asia & 182 & 38.08 \\
\hline Africa & 104 & 21.76 \\
\hline Latin America and the Caribbean (LAC) & 73 & 15.27 \\
\hline East Asia and Pacific (EAP) & 59 & 12.34 \\
\hline Eastern Europe and Central Asia (EECA) & 20 & 4.18 \\
\hline Mixed regions & 14 & 2.93 \\
\hline Western Europe & 12 & 2.51 \\
\hline Middle East and North Africa (MENA) & 10 & 2.09 \\
\hline North America & 2 & 0.42 \\
\hline Oceania & 2 & 0.42 \\
\hline Total & 478 & \\
\hline
\end{tabular}

The analysis of the distribution of keywords by region from a sustainability perspective (see Table 2) indicates that on average, $50 \%$ of the keywords are in the financial category, and $40.5 \%$ in the social category. The environment has hardly any presence; it does not exceed $3 \%$ of words in any 
region except South Asia (6.34\%). Governance has slightly higher figures-around 5\% of keywords in this dimension. EECA stands out with $14 \%$ of terms in this area.

Table 2. Classification of the keywords by region, according to the financial, social, environmental and governance (FESG) principles. Source: authors, based on the Web of Science database.

\begin{tabular}{|c|c|c|c|c|c|}
\hline \multirow{2}{*}{ Region } & \multicolumn{4}{|c|}{ FESG dimension } & \multirow{2}{*}{ Total } \\
\hline & Financial & Social & Environmental & Governance & \\
\hline South Asia & $199(47.76 \%)$ & $169(40.67 \%)$ & $26(6.34 \%)$ & $22(5.22 \%)$ & 416 \\
\hline África & $79(31.68 \%)$ & $145(58.38 \%)$ & $6(2.48 \%)$ & $19(7.45)$ & 249 \\
\hline LAC & $93(54.05 \%)$ & $68(39.64 \%)$ & $5(2.70 \%)$ & $6(3.60 \%)$ & 172 \\
\hline EAP & $70(43.27 \%)$ & $81(50.00 \%)$ & $5(2.88 \%)$ & $6(3.85 \%)$ & 161 \\
\hline EECA & $31(71.43 \%)$ & $6(14.29 \%)$ & $0(0.00 \%)$ & $6(14.29 \%)$ & 43 \\
\hline Total & 471 & 469 & 42 & 59 & 1041 \\
\hline
\end{tabular}

LAC: Latin America and Caribbean; EAP: East Asia and Pacific;

EECA: Eastern Europe and Central Africa

Therefore, in South Asia and EAP, the studies conducted are mainly socio-economic studies, whereas they were mainly social studies in Africa and financial studies in LAC. The EECA region presents research focused primarily on the financial and governance dimensions, specifically the number of governance studies is well above the average.

The analysis by region of the keywords categorized in each of the four dimensions of sustainability reveals that although common research topics exist in different regions, there are also important differences between them. See Figure 2 for a schematic view of the results obtained.

The financial and social dimensions are those with the greatest variety of topics investigated, while the environmental dimension has a very small presence. By region, in the financial dimension, it is observed that the evaluation of the performance and financial sustainability of the institutions is a common concern to all of them, as is researched on the role that these institutions play, their target market and the products and services offered.

There are exclusive aspects of South Asia, such as studies on neoliberal policies or institutional theories. The investigation of the relationship between economics and the Islamic religion is also exclusive to this region. Likewise, credit constraints and ratings are a characteristic issue for the Asian region (South Asia and EAP).

The research for Africa does not reflect the different themes from all the common ones with the other regions. LAC microfinance research stands out for its interest, exclusively for this region, on the market crisis, economic deceleration, indebtedness and repayment.

The social dimension, in a general way for all regions, focuses on the binomial poverty reduction-development increase. Besides, to this, the rural-urban collective is added. We found a large number of studies that combine the two concepts: rural/urban poverty, urban/rural development and rural microfinance. The study of poverty and the evaluation of the social impact that these institutions have is common to all of them, as an inherent part of the original role of microfinance. 
FESG Dime nsion

Topic

S. ASIA AFRICA LAC EAP EECA

\begin{tabular}{|c|c|c|c|c|c|c|}
\hline \multirow{12}{*}{$\begin{array}{l}\text { FINANCIAL- } \\
\text { ECONOMIC }\end{array}$} & Products and services & $\sqrt{ }$ & $\sqrt{ }$ & $\sqrt{ }$ & $\sqrt{ }$ & - \\
\hline & Institutions & $\sqrt{ }$ & $\sqrt{ }$ & $\sqrt{ }$ & $\sqrt{ }$ & $\sqrt{ }$ \\
\hline & Credit & $\sqrt{ }$ & - & - & $\sqrt{ }$ & - \\
\hline & Debt & $\sqrt{ }$ & - & - & $\sqrt{ }$ & $\sqrt{ }$ \\
\hline & Target & $\sqrt{ }$ & $\sqrt{ }$ & $\sqrt{ }$ & $\sqrt{ }$ & - \\
\hline & Evaluation & $\sqrt{ }$ & $\sqrt{ }$ & $\sqrt{ }$ & $\sqrt{ }$ & $\sqrt{ }$ \\
\hline & Function & $\sqrt{ }$ & $\sqrt{ }$ & $\sqrt{ }$ & $\sqrt{ }$ & - \\
\hline & SHG & $\sqrt{ }$ & $\sqrt{ }$ & - & - & - \\
\hline & Theories and policies & $\sqrt{ }$ & - & - & - & - \\
\hline & Islamic finance & $\sqrt{ }$ & - & - & - & - \\
\hline & Repayment & - & - & $\sqrt{ }$ & - & - \\
\hline & Market crisis & - & - & $\sqrt{ }$ & - & - \\
\hline \multirow{3}{*}{ ENVIRONMENTAL } & Climate change & $\sqrt{ }$ & - & $\sqrt{ }$ & $\sqrt{ }$ & - \\
\hline & Natural disasters & $\sqrt{ }$ & $\sqrt{ }$ & - & $\sqrt{ }$ & - \\
\hline & Green Microfinance & - & - & $\sqrt{ }$ & - & - \\
\hline \multirow{10}{*}{ SOCIAL } & Rural/Urban & $\sqrt{ }$ & $\sqrt{ }$ & $\sqrt{ }$ & $\sqrt{ }$ & $\sqrt{ }$ \\
\hline & Women & $\sqrt{ }$ & $\sqrt{ }$ & $\sqrt{ }$ & $\sqrt{ }$ & - \\
\hline & Children & $\sqrt{ }$ & $\sqrt{ }$ & $\sqrt{ }$ & $\sqrt{ }$ & - \\
\hline & Community & $\sqrt{ }$ & $\sqrt{ }$ & $\sqrt{ }$ & $\sqrt{ }$ & - \\
\hline & Health & - & $\sqrt{ }$ & $\sqrt{ }$ & - & - \\
\hline & Housing & $\sqrt{ }$ & $\sqrt{ }$ & - & $\sqrt{ }$ & - \\
\hline & Poverty & $\sqrt{ }$ & $\sqrt{ }$ & $\sqrt{ }$ & $\sqrt{ }$ & $\sqrt{ }$ \\
\hline & Development & $\sqrt{ }$ & - & - & - & - \\
\hline & Evaluation & $\sqrt{ }$ & $\sqrt{ }$ & - & - & $\sqrt{ }$ \\
\hline & Consecuences & $\sqrt{ }$ & - & - & - & - \\
\hline \multirow{8}{*}{ GOVERNANCE } & CG mechanisims & $\sqrt{ }$ & $\sqrt{ }$ & $\sqrt{ }$ & - & $\sqrt{ }$ \\
\hline & Employees & $\sqrt{ }$ & $\sqrt{ }$ & - & - & - \\
\hline & Organizational change & $\sqrt{ }$ & - & - & - & - \\
\hline & Corruption & $\sqrt{ }$ & - & - & - & - \\
\hline & Accountability & - & $\sqrt{ }$ & - & - & - \\
\hline & Consumer protection & - & $\sqrt{ }$ & - & - & - \\
\hline & Regulation & - & $\sqrt{ }$ & $\sqrt{ }$ & $\sqrt{ }$ & $\sqrt{ }$ \\
\hline & Mission drift & - & - & $\sqrt{ }$ & - & - \\
\hline
\end{tabular}

\section{S. Asia: South Asia}

LAC: Latin America and the Caribbeann

EAP: East Asia and the Pacific

EECA: Eastern Europe and Central Asia $\sqrt{ }$ Issue considered

- Issue not considered

Figure 2. Aspects treated in each of the financial, social, environmental and governance (FESG) dimensions by region. (Source: authors).

There is also widespread attention to the vulnerability of three collectives-women, children and community-but there are differences by region. When the effect of microfinance on the collective of women is investigated, in most cases, it is related to empowerment, relationship power and discrimination. However, in the case of Africa and South Asia, the intimate partner violence in the studies becomes very important. In the case of children, the differences between the three regions 
are notable. In the case of Africa, studies focus on orphaned children and depression. In South Asia, they focus on child mortality, malnutrition and education - and in the case of LAC, on child labor, education and schooling gaps. In the case of the community, the regions of Africa focus on fishing communities, mobilization and training programs, those of South Asia on the tribe's development, and those of LAC on ethnography and solidarity groups.

The effect of microfinance on health and housing supplies also differs by region. In the case of health, in the regions of Africa and LAC, it becomes especially relevant to HIV, disabilities, prevention and access to health services, and the effects of malaria in the specific case of Africa. In the case of the South Asia region, and directly linked to the women's group, access to health and contraceptive methods also appears. The household decision-making and family economic strengthening-also related to gender-is a key issue in Africa, and in South Asia and EAP, water supply, sanitation and housing conditions prevail.

Keywords from the studied papers, related to the environmental dimension, are reduced to three aspects: climate change, natural disasters and green microfinance, which refers to those microfinance products that tend to promote sustainable activities, a more efficient use of resources and the reduction of environmental risks, among others. In the South Asia region, climate change is related to eco-friendly technologies and energy, and fundamentally to natural disasters due to deforestation and the tsunami that occurred in 2004. The keyword green microfinance arises exclusively in the LAC region.

Investigations in which governance aspects are considered, have in common the study of corporate governance mechanisms and regulation. There are specific aspects such as corruption in South Asia in which academia points out the need for strong monitoring, high internal audit, anti-corruption cultures and transparency. This also connects with Africa's situation, where accountability and consumer protection, such as clear debt collection practices, the prevention of over-indebtedness, or the clear disclosures of prices and conditions are important matters. In the LAC region, highlighted is the concern about mission drift, in which the trade-off between being a profitable MFI and outreach, compromises the initial organizational social objectives.

\subsection{Findings From the MIX Market}

The initial population was 1394 MFIs registered in The MIX Market database in 2017. After applying the selection criteria 'number of institutions that have sustainability data', 1124 MFIs from the sample remained. By this point, the sample had been reduced by $20 \%$. A drastic reduction occurred when introducing the minimum levels of quality disclosure, with a reduction of $75 \%$. The definitive sample was 281 MFIs. (See Table 3.)

Table 3. Classification by region of the number of Microfinance Institutions (MFIs) with sustainability data available and with a diamond rating of more than three. (Source: authors, based on the MIX Market data.).

\begin{tabular}{|l|c|c|c|c|c|c|c|c|c|}
\hline & \multirow{2}{*}{$\begin{array}{l}\text { Total } \\
\text { MFIs }\end{array}$} & \multirow{2}{*}{$\begin{array}{c}\text { Sus tainability data } \\
\text { available }\end{array}$} & \multicolumn{5}{|c|}{$\begin{array}{c}\text { Quality dis clos ure } \\
\text { (diamonds) }\end{array}$} & $\begin{array}{c}\text { Number of MFIS with } \\
\text { more than 3 diamonds }\end{array}$ \\
\cline { 4 - 8 } & & 296 & 42 & 3 & 51 & 124 & 50 & 26 & 225 \\
\hline LAC & 845 & 219 & 46 & 77 & 4 & 10 & 2 & 80 & 16 \\
\hline EECA & 553 & 106 & 16 & 51 & 0 & 11 & 4 & 24 & 15 \\
\hline EAP & 473 & 203 & 19 & 125 & 1 & 8 & 2 & 48 & 11 \\
\hline South Asia & 503 & 268 & 104 & 60 & 4 & 3 & 1 & 96 & 8 \\
\hline Africa & 920 & 32 & 9 & 13 & 0 & 5 & 1 & 4 & 6 \\
\hline MENA & 117 & $\mathbf{1 1 2 4}$ & 236 & 329 & 60 & 161 & 60 & 278 & $\mathbf{2 8 1}$ \\
\hline Total & $\mathbf{3 4 1 1}$ & 236 &
\end{tabular}

LAC: Latin America and Caribbean; EECA: Eastern Europe and Central Africa

EAP: East Asia and Pacific; MENA: Middle East and North Africa 
In the initial population, more than $50 \%$ of the institutions belong to the LAC and Africa regions. LAC, Africa, EECA and South Asia represent $82 \%$ of the institutions.

Of the total number of institutions, only $33 \%$ provide data related to sustainability dimensions, and when introducing the quality of information variable, it is observed that $61 \%$ of organizations have one or two diamonds, $36 \%$ are undetermined and 3\% have a ranking equal to or greater than three. Africa is the region with the worst data in terms of diamonds. $97 \%$ of institutions are in the lower or undetermined ranges. The rest of the regions, except LAC, on average, have two diamonds-that is, they offer some financial data for the year. LAC is the only region with more than half of the institutions being above-average, where $59 \%$ of organizations have four or five diamonds-that is, they offer audited financial statements, and ratings or diligence reports are published for the year.

The analysis was based on 72 SIs. 16 of them were eliminated due to the low response rate $-15 \%$ or more missing data. Of these, four were from Women's empowerment services, three from environment, eight related to audit and rating, and one from client protection. See Figure 2 for the description of the different SIs analyzed and the nomenclature used to refer to each of them.

The Kruskal-Wallis $\mathrm{H}$ test analysis indicates that only six indicators follow a similar distribution per region: (1) express loans as income-generating loans in the financial dimension, (2) adolescents and youth (below 18) as the target market, (3) clients living in rural/urban areas as the target market, (4) the improvement of adult education as a development goal, (5) the MFI has a robust repayment evaluation in the social dimension and (6) human resource policies include social protection in the governance dimension. It indicates that $89 \%$ of indicators do not follow a similar distribution by region. That is, MFIs behave statistically differently depending on the region in which they are located; therefore, it is required that the results of the study are performed with consideration to the regions, and not exclusively globally.

In the financial dimension, the products with the highest affirmative response rates are microenterprise loans (91\%) offered by almost all MFIs, agricultural and livestock loans $(68 \%)$, and loans for other household needs (58\%). The products or services with the lowest offer by the institutions are health services (18\%), emergency loans (5\%) and express loans ( $2 \%)$.

The figures vary slightly by region according to products. Note that in non-financial services, non-financial services to companies, other educational services and health services, the South Asia region presents percentages higher than the average for all $(16 \%, 12.5 \%$ and $25 \%$ above the mean respectively). That is, in the South Asia region, the offer of products and services is more diversified than in the rest of the regions. However, EECA is the opposite case, in which all figures are lower than in the other regions. On average, non-financial services are offered by $15 \%$ fewer institutions than in other regions.

The most-reported social indicators are those that indicate that the increase of access to financial services and poverty reduction are development goals of the MFI ( $81 \%$ and $78 \%$ respectively), and that women are one of their target markets (80\%). Among the least reported are children's schooling, and access to water and sanitation as development goals ( $28.5 \%$ and $24 \%$ respectively). There is a contradiction that, despite the reduction of poverty being among the most reported aspects, having very poor clients as a goal is the aspect least considered by MFIs (26\%).

In general, LAC values remain close to the average in all indicators. Africa has a greater interest in increasing access to financial services (88\%) and schooling (37\%) than the general average $(81 \%$ and $28.5 \%$ respectively). South Asia is the only region in which all reported social indicators are in line with the average, or above. They report measuring poverty by $25 \%$ more than the average, their objectives of improving health and access to water and sanitation are $17 \%$ above the average, and the equality and empowerment of women exceeds the average by $11 \%$ in general. On the contrary, EAP is the only region in which when the indicators are not reported, they are similar to the average. It is because they do so with lower values. In this sense, the least reported indicators are those related to business and employment. These are employment generation $(-12 \%)$, the growth of existing businesses $(-9 \%)$ and opportunities for young people $(-13 \%)$. 
Concerning customer protection, the percentage of affirmative responses is high. On average, $80 \%$ of institutions responded to carry out actions related to customer protection. The indicators with the largest number of institutions are robust repayment evaluation and full disclosure of prices, both with $89 \%$.

MFIs in South Asia largely report the indicators related to client protection. Having a functioning client complaint mechanism (which was $21 \%$ above the average), carrying out clear debt collection practices and internal audits to verify over-indebtedness prevention, were $15 \%$ above the general average. The EECA region is the one that gives the best data for the privacy data clause in loan contracts $(88.5 \%)$, and LAC presents the worst results concerning the prevention of over-indebtedness, since only $64 \%$ of institutions positively report this indicator.

In the environmental dimension, the response rate of the indicators in this category is lower than in the previous ones (19\%). The general average of institutions that carry out environmental actions is low (26\%). The indicator with the lowest percentage of affirmative answers is 'the institution includes clauses in loan contracts that require clients to improve environmental practices/mitigate environmental risks' (18\%). The one that is supported largely is 'the institution carries out related activities to raise awareness about environmental impacts, such as: organize training sessions and debates, display posters, distribute flyers, etc.' with $40 \%$ of answers being affirmative.

By region, the one with the best results is South Asia, since three of the four indicators studied have better results than in the other regions. The number of institutions that perform environmental actions is $10 \%$ higher than the general average.

For the governance dimension, the four indicators related to human resources policies are the ones that present the greatest dispersion. The indicator 'the MFI has a non-discrimination policy' is the most reported indicator of the 12 analyzed, with $85 \%$ institutions that consider the action. None exceeds $7.5 \%$ of affirmative answers. Therefore, the numbers of institutions that present a safety policy, an anti-harassment policy or a grievance resolution policy are practically non-existent $(6.5 \%, 6.7 \%$, and $7.47 \%$ respectively). Regarding the incentives for the staff, the number of clients and the quality of the portfolio are considered by the institutions ( $75 \%$ and $80 \%$ respectively), while the quality of the social data is represented by a residual value $(16 \%)$.

The regions with extreme values in this category are South Asia and Latin America. LAC, in general, presents data slightly below the average except in the human resources policy indicators, in which the results are significantly worse. Only $2.36 \%$ of institutions report having anti-harassment policies, $2.70 \%$ have a safety policy and $1.7 \%$ of institutions indicate that they apply grievance resolutions. South Asia, however, presents above-average results in practically all indicators in this area. This region reports positively to most of the indicators related to government boards committed to the mission and social performance ( $20 \%$ above average), personnel incentive bases not conditional on the number of clients but on the quality of social data ( $6.5 \%$ above average), and human resources policies of greater protection for the employee (7.5\% above average).

To reflect the degree to which each of the indicators is considered by region, Figure 3 shows the percentage of institutions that respond affirmatively to each sustainability indicator by region suggested by the MIX Market.

\subsection{Findings Combining the Two Sources of Information}

When academic research documents are compared with the number of institutions that report their activities by region, we find that in South Asia, Africa and EAP, the information we manage almost exclusively proceeds from research. In the case of LAC, the situation is inverse; the number of articles in this region is low compared to the number of institutions that present their sustainability data (see Figure 4). For the EECA and MENA regions, information regarding sources of information is similar, although practically non-existent. 
FINANCIAL

\begin{tabular}{|l|l|l|l|l|l|l|l|l|l|l|l|l|l|l|l|l|}
\hline Region & FC1 & FC2 & FC3 & FC4 & FC5 & FC6 & FC7 & FC8 & FC9 & FC10 & FC11 & FC12 & FC13 & FC14 & FC15 & FC16 \\
\hline LAC & & & & & & & & & & & & & & & \\
\hline EECA & & & & & & & & & & & & & & & \\
\hline EAP & & & & & & & & & & & & & & & \\
\hline S ASIA & & & & & & & & & & & & & & \\
\hline AFRICA & & & & & & & & & & & & & & \\
\hline MENA & & & & & & & & & & & & & & & &
\end{tabular}

SOCIAL

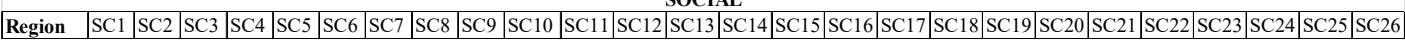

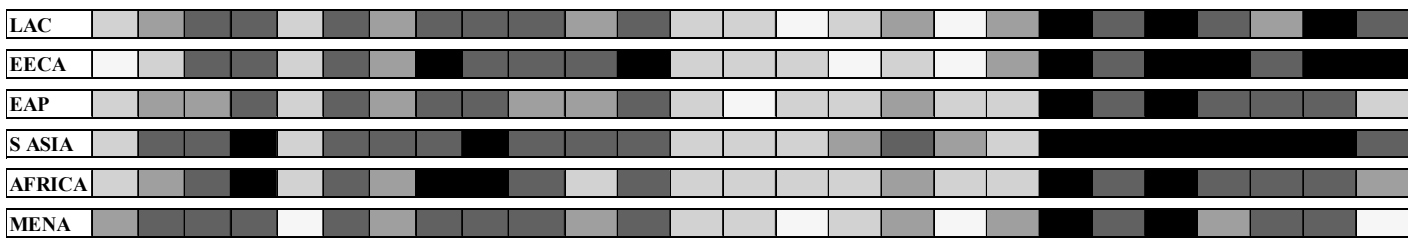

GOVERNANCE

\begin{tabular}{|l|l|l|l|l|l|l|l|l|l|l|l|}
\hline Region & GV1 & GV2 & GV3 & GV4 & GV5 & GV6 & GV7 & GV8 & GV9 & GV10 \\
\hline
\end{tabular}

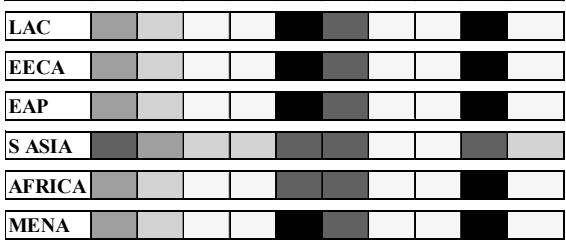

ENVIRONMENTAL
\begin{tabular}{|l|l|l|l|l|}
\hline Region & EN1 & EN2 & EN3 & EN4 \\
\hline
\end{tabular}
\begin{tabular}{|l|l|l|l|l|}
\hline LAC & & & & \\
\hline EECA & & & & \\
\hline
\end{tabular}
\begin{tabular}{|l|l|l|l|l|}
\hline EAP & & & & \\
\hline
\end{tabular}
\begin{tabular}{|l|l|l|l|l|}
\hline S ASIA & & & & \\
\hline
\end{tabular}
\begin{tabular}{|l|l|l|l|l|}
\hline AFRICA & & & & \\
\hline
\end{tabular}
$\square 0 \%-20 \%$ Afirmative response to the indicator
$\square 20 \%-40 \%$ Afirmative response to the indicator
$\square 40 \%-60 \%$ Afirmative response to the indicator
$60 \%-80 \%$ Afirmative response to the indicator
$80 \%-100 \%$ Afirmative response to the indicator
LAC: Latin America and Caribbean; EECA: Eastern Europe and Central Asia
EAP: East Asia and Pacific; S Asia: South Asia; MENA: Middle East and North Africa

Figure 3. By region, the percentage range of affirmative responses in the different financial, environmental, social and governance (FESG) dimensions and by the Sustainability Indicator (SI). (Source: authors).

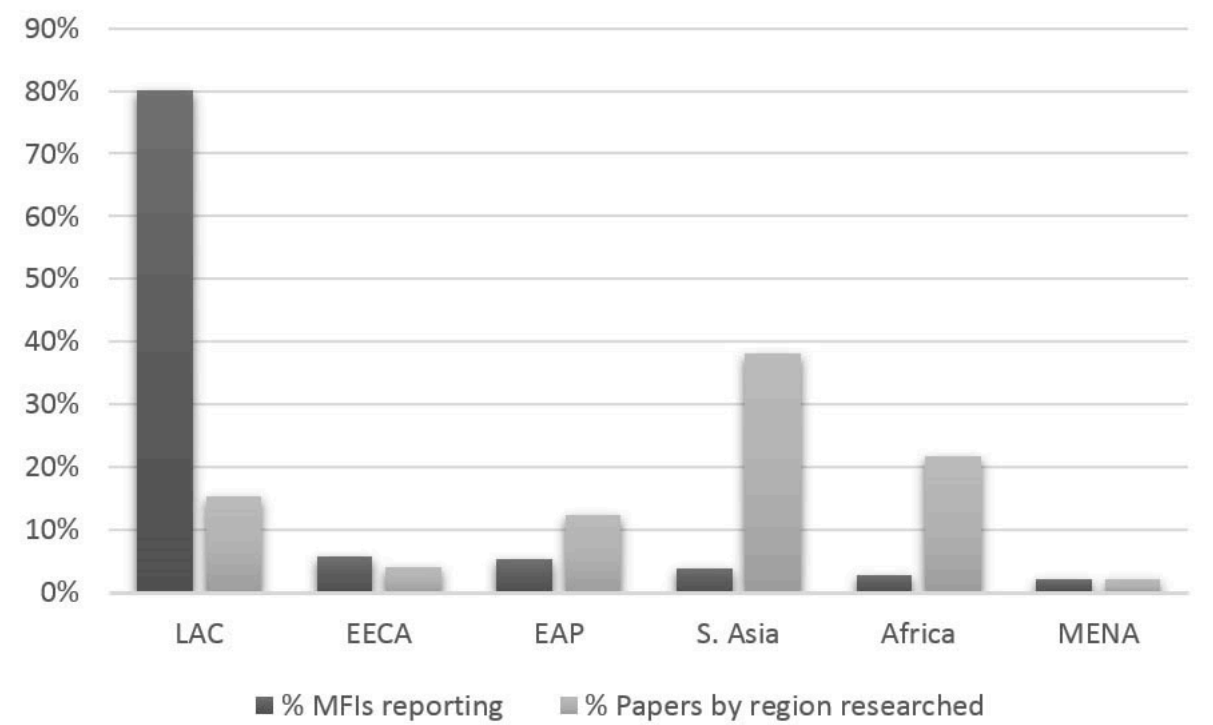

Figure 4. Comparison by region of the percentage of Microfinance Institutions (MFIs) that report sustainability data, and the percentage of papers researching the region. (Source: authors). 
Having studied, firstly, the academic literature and its keywords by region, and secondly, the reporting by the MFIs of the different sustainability indicators proposed by MIX Market, we proceed to the combined analysis of the two sources of information. As shown in Figure 5, this analysis reveals links and gaps between the main aspects reported and the main aspects studied by region.

\begin{tabular}{|l|c|c|c|c|c|c|c|c|c|c|c|c|c|c|c|c|c|c|c|c|}
\hline Region & FC1 & FC2 & FC3 & FC4 & FC5 & FC6 & FC7 & FC8 & FC9 & FC10 & FC11 & FC12 & FC13 & FC14 & FC15 & FC16 \\
\hline LAC & & & & & I & & R & R & & & R & & & & & I \\
\hline Africa & & R & & & R & & & & R & R & R & & & & R & I \\
\hline EECA & R & R & & & & & R & R & & & & & & & & \\
\hline S. Asia & & & & & I & & & & & & R & & & & & \\
\hline EAP & & & & & & & & & R & R & & & & & & I \\
\hline
\end{tabular}

SOCIAL

\begin{tabular}{|l|l|l|l|l|l|l|l|l|l|l|l|l|l|l|l|l|l|l|l|l|l|l|l|l|l|l|l|}
\hline Region & $\mathrm{SC} 1$ & $\mathrm{SC} 2$ & $\mathrm{SC} 3$ & $\mathrm{SC} 4$ & $\mathrm{SC} 5$ & $\mathrm{SC} 6$ & $\mathrm{SC} 7$ & $\mathrm{SC} 8$ & $\mathrm{SC} 9$ & $\mathrm{SC} 10$ & $\mathrm{SC} 11$ & $\mathrm{SC} 12$ & $\mathrm{SC} 13$ & $\mathrm{SC} 14$ & $\mathrm{SC} 15$ & $\mathrm{SC} 16$ & $\mathrm{SC} 17$ & $\mathrm{SC} 18$ & $\mathrm{SC} 19$ & $\mathrm{SC} 20$ & $\mathrm{SC} 21$ & $\mathrm{SC} 22$ & $\mathrm{SC} 23$ & $\mathrm{SC} 24$ & $\mathrm{SC} 25$ & $\mathrm{SC} 26$ \\
\hline
\end{tabular}

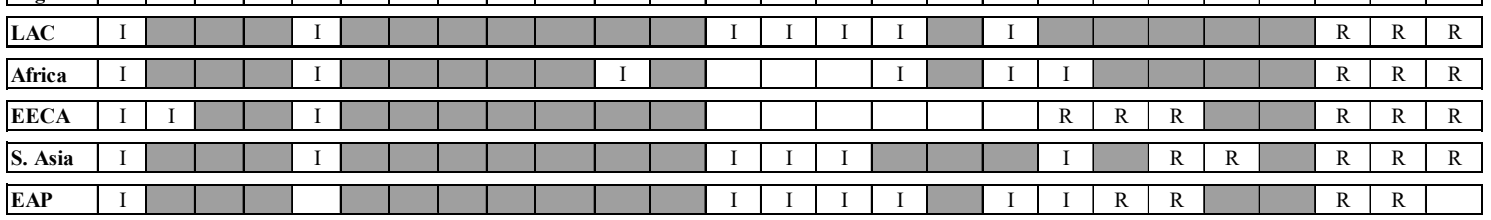

GOVERNANCE

\begin{tabular}{|l|l|l|l|l|l|l|l|l|l|l|l|}
\hline Region & GV1 & GV2 & GV3 & GV4 & GV5 & GV6 & GV7 & GV8 & GV9 & GV10 \\
\hline
\end{tabular}

\begin{tabular}{|l|l|l|l|l|l|l|l|l|l|l|}
\hline LAC & & & & & & & & & R & \\
\hline Africa & & & & & & & & & R & \\
\hline EECA & & & & & R & R & & & R & \\
\hline S. Asia & & & & & R & R & & & R & \\
\hline EAP & R & & & & R & R & & & R & \\
\hline
\end{tabular}

ENVIRONMENTAL

\begin{tabular}{|c|c|c|c|c|c|c|}
\hline \multicolumn{5}{|c|}{ ENVIRONMENTAL } & \multirow{2}{*}{\multicolumn{2}{|c|}{ Convergences: common aspects between literature and reporting }} \\
\hline Region & EN1 & EN2 & EN3 & EN4 & & \\
\hline LAC & I & I & I & I & $\mathrm{R}$ & Divergences: reported but not investigated \\
\hline Africa & & & & & I & Divergences: investigated but not reported \\
\hline EECA & & & & & & Gaps: aspects not considered \\
\hline S. Asia & & I & I & I & LAC & Latin America and Caribbean; EECA: Eastern Europe and Central Asia \\
\hline EAP & & I & I & I & EA & East Asia and Pacific; S Asia: South Asia; MENA: Middle East and North Africa \\
\hline
\end{tabular}

Figure 5. Analysis by region of the convergences, divergences and gaps between the Microfinance Institutions' (MFIs') positive Sustainability Indicator (SI) reporting and academic literature topics. (Source: authors).

\subsubsection{Convergences: Reported and Researched}

Agricultural [66-68] and microenterprise loans $[47,48,69]$ are financial aspects that are relevant to scientific research and that institutions report positively for all regions. Two other aspects which are widely investigated issues and are also reported in Africa, South Asia, and EAP regions are loans for other households' needs [39,68] and other education services [70,71]. From the point of view of the regions, the greatest convergences occur in the Asian region (South Asia and EAP). The region with the lowest convergence is EECA in which only the rural/urban dichotomy is taken into account (FC3).

There are social aspects that are broadly studied in the literature, and in turn considered by the MFIs: poor and low-income clients [69,72,73], women [45,49,74] and clients living in rural areas [52,68], among others, and the combination of them [39,46,75]. Measures of client poverty [39,76], increased access to financial services $[77,78]$, poverty reduction $[79,80]$, employment generation and the growth of existing businesses [81,82], and clear debt collection practices [83-85] are reported and also researched in all regions. There are also numerous contributions of articles with a combination of two or more issues [10]. In general, all regions have a similar level of convergence.

No aspect of the governance area meets research and reporting in all regions. Board orientation on social mission and goals $[86,87]$ is the only one considered in four of the five regions studied. 
Literature and affirmative responses related to environmental aspects and indicators only concur in the Asian region when considering the activities of the institutions to raise awareness of environmental impacts [18]. In the governance and environmental dimensions, both research and positive reporting are less frequent. As for regions, the level of convergence of the two dimensions is low for all of them.

In general, converging attributes between academic literature and sustainability indicators are related to the intrinsic aspects of microfinance. Poverty reduction, access to financial services, and access to non-financial services for health or education, among others, are those specific characteristics of microfinance activity. MFIs show their participation in these differentiating goals, and scientific literature investigates how the institutions materialize them to a greater or lesser extent. Considering the regions, it is observed that financial indicators of the EECA region could be reviewed to achieve greater convergence between report and investigation. For all regions, further research in governance is needed and greater environmental involvement by the MFIs is required.

\subsubsection{Divergences}

On the one hand, there are sustainability indicators that are informed by the MFIs and that are not reflected in the scientific literature. In the case of the financial dimension, it is the hiring of compulsory insurance (FC11). In the social dimension, they are internal audits that verify over-indebtedness prevention (SC21), functioning client complaint mechanisms (SC24), privacy data clauses in loan contracts (SC25) and declining balance interest rate calculation methods (SC26). In the area of governance, they are specific internal aspects of the institution such as staff incentives based on portfolio quality (GV5), social protection (GV6), and non-discriminatory policies for employees (GV9). There are no reported and non-investigated environmental indicators.

On the other hand, some issues are important for research, and yet they are not carried out by the institutions. In the case of the financial area, health services are an aspect that is relevant for research in regions such as LAC [36], Africa [50] and EAP [43,88]; however, they do not have an affirmative answer from the MFIs. The same circumstance is given for education loans for the LAC [89] and S. Asia $[71,74]$ regions. In the social dimension, the great forgotten for all regions are the very poor clients (SC1), and adolescents and youth (SC5) as a target for MFIs, while in the scientific literature, their presence is noticeable $[72,73,90,91]$. The same happens with certain development goals, such as the improvement of adult education (SC13) that is investigated in all regions except EAP $[51,52,68]$, youth opportunities (SC14) [18], children's schooling (SC15) [71], health improvement (SC16) [71,82,92] and access to water and sanitation (SC18) $[43,93]$. These are the four goals that are investigated in LAC, South Asia, and EAP and that do not find a positive report in the database.

For governance, while research tends to be relatively scarce [10] and aspects related to governance mechanisms are generic [28,87], the indicators present in the database and reported by the institutions are specific. In the environmental dimension, research has a relevant role. The affirmative response rate by MFIs to these indicators is practically nil. Therefore, information about the relationship between microfinance and the environment is obtained almost exclusively from the scientific literature $[18,80,94]$ for the regions of LAC, South Asia and EAP, without being performed actions by the institutions.

There are also research topics, specific to certain regions, which are not associated with any SI present in the MIX Market database. We found that in the financial dimension, Islamic banking is a relevant issue in EAP and South Asia $[40,95,96]$, and the financial crisis and market saturation [97-99] are relevant issues in the LAC region; environmental issues like climate change [100,101], natural disasters [102] or the 2004 tsunami [103-105] are significant in Asia, and in the case of governance, the specific aspects investigated and not reported by region are corruption in South Asia $[69,106]$, and accountability in Africa $[107,108]$. Concern for regulation is broadly researched and extends to all regions $[28,109,110]$, among others.

In the divergences observed when reported affirmatively but not investigated, it usually refers to specific aspects of the internal functioning of the MFIs. In the divergences in which it is investigated but not positively reported, these are the pending subjects of microfinance programs such as the offer 
of non-financial services associated with health, education and basic needs, as well as the monitoring of the environmental consequences outside the institution, derived from the granting of microcredits.

The divergences in which the scientific literature does not find defined sustainability indicators reported by the institutions indicates the need to add specific items by region that respond to the particularities of each market.

\subsubsection{Gaps: Not Reported and Not Researched}

Three financial indicators are not reported by the institutions or investigated by the academy. These are express and emergency loans (FC4, FC6) and voluntary insurance (FC12). The EECA region is the one with the most gaps in this area.

The improvement of adult education (SC13), youth opportunities (SC14), and children's schooling (SC15) have gaps in the social area for the regions of EECA and Africa. In the case of the EECA region, these minimum standards are covered, so MFIs do not need to meet that need, while in the Africa region, social objectives are focused on more basic development goals (SC6, SC7, SC8, SC9) [111], the microenterprises and businesses (SC10, SC11, and SC12), and customer protection against indebtedness (SC23). In the EECA region, it should be added that neither health improvement (SC16) nor access to water and sanitation (SC18) is investigated or reported, since these are basic needs covered for the majority of the population to a certain extent. It is noteworthy that it is the only region that does not positively report gender equality and the women's empowerment indicator (SC17), and which in turn is not a relevant aspect for research [16].

For the governance dimension, the specific aspects associated with the composition of the members of the committee (GV2 and GV3) and human resource policies (GV4, GV7, GV8 and GV10) are not priority topics for research, nor are the institutions themselves reported affirmatively. Therefore, information about MFI employees is scarce. In the Africa and EECA regions, none of the environmental indicators are investigated or reported. This situation is especially serious in the case of Africa due to the large number of institutions that operate-about 900 institutions—and the large number of clients served, around 54 million active borrowers [14].

There are indicators without reporting and research that should be reviewed. For example, indicators about products that are not demanded or offered could be eliminated, and in regions where basic social needs are covered, certain indicators could be replaced with others that fit their realities. For the EECA region, it would be necessary to review the financial and social indicators to better fit their market. However, there may be the fact that these gaps are showing some sustainability indicators that need an in-depth analysis of why the MFIs are not carrying out actions and why academic literature is not investigating, for example, governance mechanisms for all regions or environmental aspects in the Africa region.

\section{Discussion and Conclusions}

The purpose of this paper was to explore to what extent microfinance institutions are fostering SD differently depending on geographic area, and why. To assess how institutions are promoting sustainability, two high quality and complementary sources of information were analyzed: microfinance sectoral academic literature and the MIX Market database, with information voluntarily reported by the MFIs.

The objective was to build on these gaps and provide insightful information to help to characterize the microfinance sector at a regional level. Once the data were obtained from each one of the information sources, coincidences and divergences in the different aspects and features were analyzed, as well as the research gaps of each source, individually and jointly, for each of the regions.

The South Asia region, the most matured in microfinance, reports-affirmatively-the largest offering of financial and non-financial products and services. Additionally, as an exclusive feature of the Asian area, arises Islamic banking and how its singularities could affect the context of the MFIs. Social aspects in which special attention is required, since they are investigated but not reported 
positively, revolve around women, children and housing-women's empowerment, contraceptive methods, child mortality, malnutrition, education, sanitation and housing conditions. Corruption is the most disquieting governance aspect. Given its position as a producing region and due to its financial maturity, environmental analysis is emerging.

The context of EAP is conditioned by the 2004 tsunami, so research takes into account the effect of natural disasters and climate change. In this case, it is necessary to be cautious when considering this interest as an attention to the sustainability dimension, since the approach that is being carried out is related to how microfinance can help mitigate the economic consequences of a natural disaster, and not to the fact that the destination of the financing granted by the MFIs is respectful of the environment. Also, in this Asian region, the Islamic religion is deeply rooted, so Islamic banking is a matter for study and comparison with the microfinance system. It is detected that the improvements that institutions can make in the social section are similar to those in South Asia, with attention to opportunities for women and young people, early childhood education, health service development and the improvement of housing conditions with access to water and sanitation, as priorities.

Most of the information about the MFIs of Africa and their activities proceeded from academic literature since the quality standards of the reporting in this region are very low. This situation is highly alarming given the large number of institutions operating along the continent and the high number of active borrowers served in this region. In addition, this lack of transparency has a direct negative effect on the information received by donors and investors, which directly undermines the establishment of good mechanisms for the allocation of funds to this region. A way to begin to strengthen the governance dimension is, as demanded from the academic field, greater consumer protection and accountability from the institutions located in Africa. Unlike the South Asia and EAP regions, despite the high number of Islamic populations, no research on Islamic banking has yet been carried out in this region. Considering the development context of the Africa region, there are four large groups in which the institutions have a great improvement path; these four big clusters are women (gender inequalities, inter-partner violence and household decision-making), childhood (orphaned children and schooling), health (HIV and malaria) and basic services (access to water and sanitation). So far, there are no signs of which environmental dimension is going to take a leading role in this context.

In the LAC region, as a consequence of its financial context, it is the only area in which market crisis, deceleration and market saturation are discussed. The most significant social aspects for these institutions are gender equality and education, and those aspects in which work remains to be done, since they are not reported affirmatively, are access to water and sanitation, and health improvement. Although the MFIs in LAC do not declare to perform actions that have a positive impact on the environment, research begins to talk about green microfinance, and the materialization of financial products and services to protect their client portfolio from specific vulnerabilities and risks due to climate change impacts. LAC MFIs, in terms of governance, highlight the important role that equity investors play-unlike in Africa, the degree of transparency in this region is high, and the proportion of institutions that report with high-quality standards is well above the average of the other regions.

Microfinance in EECA and MENA regions is less representative. The weight of these regions in the total microfinance activity is relatively low ( $4.5 \%$ and $1 \%$ respectively) and this is reflected in the number of papers dedicated to these regions, as well as the number of institutions that report their activity. It would be necessary to conduct an in-depth analysis to assess whether the microfinance system, as currently defined, is useful in these regional contexts, and to also review the indicators-especially financial and social—-that better fit the market.

For further research, it would be advisable that a holistic approach prevails in the study of the MFIs' performance; there is also an urgent need for greater transparency by these institutions that could be constructive for all stakeholders, private sector investment and the international donor community. 
Author Contributions: conceptualization, M.Á.F.-I.; methodology, I.G.-P.; software, I.G.-P.; validation, I.G.-P., M.Á.F.-I., and M.J.M.-T.; formal analysis, I.G.-P.; investigation, I.G.-P.; resources, I.G.-P.; data curation, I.G.-P.; writing-original draft preparation, I.G.-P.; writing—review and editing, M.J.M.-T., and M.Á.F.-I.; visualization, I.G.-P., M.J.M.-T., and M.Á.F.-I.; supervision, M.J.M.-T., and M.Á.F.-I.; project administration, M.J.M.-T., and M.Á.F.-I.; funding acquisition, M.J.M.-T., and M.Á.F.-I. All authors have read and agreed to the published version of the manuscript.

Funding: This paper is supported by European Union's Horizon 2020 Research and Innovation Programme under Grant Agreement No. 693642, project SMART (Sustainable Market Actors for Responsible Trade).

Conflicts of Interest: The authors declare no conflict of interest.

\section{References}

1. Convergences Barometers. Microfinance Barometer 2018; Convergences: Paris, France, 2018.

2. Hassan, M.K.; Sanchez, B.; Yu, J.S. Financial development and economic growth: New evidence from panel data. Q. Rev. Econ. Financ. 2011, 51, 88-104. [CrossRef]

3. Hudon, M. Should access to credit be a right? J. Bus. Ethics 2009, 84, 17-28. [CrossRef]

4. García-Pérez, I.; Muñoz-Torres, M.J.; Fernández-Izquierdo, M.Á. Microfinance institutions fostering sustainable development. Sustain. Dev. 2018, 26, 606-619. [CrossRef]

5. Brundtland, G.H.; Khalid, S.; Agnelli, M.; Al-Athel, S.; Chidzero, B. Our common Future; Oxford University Press: Oxford, UK, 1987.

6. Gladwin, T.N.; Kennelly, J.J.; Krause, T. Shifting Paradigms for Sustainable for Implications Development: And Theory. Acad. Manag. Rev. 1995, 20, 874-907. [CrossRef]

7. Starik, M.; Kanashiro, P. Toward a Theory of Sustainability Management: Uncovering and Integrating the Nearly Obvious. Organ. Environ. 2013, 26, 7-30. [CrossRef]

8. Lozano, R.; Huisingh, D. Inter-linking issues and dimensions in sustainability reporting. J. Clean. Prod. 2011, 19, 99-107. [CrossRef]

9. World Bank. Poverty and Shared Prosperity 2018: Piecing Together the Poverty Puzzle; World Bank: Washington, DC, USA, 2018.

10. García-Pérez, I.; Muñoz-Torres, M.-J.; Fernández-Izquierdo, M.-Á. Microfinance literature: A sustainability level perspective survey. J. Clean. Prod. 2017, 142, 3382-3395. [CrossRef]

11. van Rooyen, C.; Stewart, R.; de Wet, T. The Impact of Microfinance in Sub-Saharan Africa: A Systematic Review of the Evidence. World Dev. 2012, 40, 2249-2262. [CrossRef]

12. Morduch, J.; Morduch, J. The Microfinance Promise. J. Econ. Lit. 1999, 37, 1569-1614. [CrossRef]

13. Khandker, S.R. Microfinance and poverty: Evidence using panel data from Bangladesh. World Bank Econ. Rev. 2005, 19, 263-286. [CrossRef]

14. Khamar, M. Global Outreach \& Financial Performance Benchmark Report-2017-2018; Report prepared for MIX.; Microfinance Information Exchange: Washington, DC, USA, 2018; Available online: www.themix.org (accessed on 15 February 2020).

15. Hofstede, G. Culture's Consequences: International Differences in Work-related Values; SAGE Publications Ltd.: London, UK; New Delhi, India, 1980.

16. Armendariz, B.; Szafarz, A. On mission drift in microfinance institutions. In The Handbook of Microfinance; World Scientific Publishing Co Pte Ltd.: Singapore, 2011; pp. 341-366.

17. Gutierrez-Nieto, B.; Serrano-Cinca, C.; Molinero, C. Social efficiency in microfinance institutions. J. Oper. Res. Soc. 2009, 60, 104-119. [CrossRef]

18. Archer, G.R.; Jones-Christensen, L. Entrepreneurial value creation through green microfinance: Evidence from Asian microfinance lending criteria. Asian Bus. Manag. 2011, 10, 331-356. [CrossRef]

19. Ledgerwood, J. Microfinance Handbook: An. Institutional and Financial Perspective; The World Bank: Washington, DC, USA, 1998.

20. Widiarto, I.; Emrouznejad, A.; Anastasakis, L. Observing choice of loan methods in not-for-profit microfinance using data envelopment analysis. Expert Syst. Appl. 2017, 82, 278-290. [CrossRef]

21. Dyllick, T.; Hockerts, K. Beyond the business case for corporate sustainability. Bus. Strateg. Environ. 2002, 11, 130-141. [CrossRef] 
22. Rockström, J.; Steffen, W.; Noone, K.; Persson, A.; Chapin, F.S.; Lambin, E.F.; Nykvist, B.; Lenton, T.M.; Crutzen, P.; Svedin, U.; et al. A safe operation space for humanity. Nature 2009, 461, 472-475. [CrossRef]

23. Steffen, W.; Richardson, K.; Rockström, J.; Cornell, S.E.; Fetzer, I.; Bennett, E.M.; Folke, C.; Gerten, D.; Reyers, B.; Persson, L.M.; et al. Planetary boundaries: Guiding human development on a changing planet. Science 2015, 347, 1259855. [CrossRef]

24. World Commission of Environment and Development. Our Common Future; Oxford University Press: Oxford, UK, 1987.

25. Warnecke, T. 'Greening' gender equity: Microfinance and the sustainable development agenda. J. Econ. Issues 2015, 49, 553-562. [CrossRef]

26. Mersland, R.; Øystein Strøm, R. Performance and governance in microfinance institutions. J. Bank. Financ. 2009, 33, 662-669. [CrossRef]

27. Hartarska, V.; Nadolnyak, D. Do regulated microfinance institutions achieve better sustainability and outreach? Cross-country evidence. Appl. Econ. 2007, 39, 1207-1222. [CrossRef]

28. Hartarska, V. Governance and performance of microfinance institutions in Central and Eastern Europe and the newly independent states. World Dev. 2005, 33, 1627-1643. [CrossRef]

29. Ramaswamy, A.; Krishnamoorthy, A. The Nexus Between Microfinance \& Sustainable Development: Examining The Regulatory Changes Needed For Its Efficient Implementation. Eur. J. Sustain. Dev. 2016, 6, 453-460.

30. Chakrabarty, S.; Bass, A.E. Comparing Virtue, Consequentialist, and Deontological Ethics-Based Corporate Social Responsibility: Mitigating Microfinance Risk in Institutional Voids. J. Bus. Ethics 2015, 126, 487-512. [CrossRef]

31. Copestake, J.; Johnson, S.; Wright, K. Impact Assessment of Microfinance: Towards a New Protocol for Collection and Analysis of Qualitative Data. Work. Pap. 2002, 44, 1-23.

32. Rogaly, B. Micro-finance evangelism, 'destitute women', and the hard selling of a new anti-poverty formula. Dev. Pract. 1996, 6, 100-112. [CrossRef]

33. Shaw, J. Microenterprise Occupation and Poverty Reduction in Microfinance Programs: Evidence from Sri Lanka. World Dev. 2004, 32, 1247-1264. [CrossRef]

34. Prasad, D.B. Beyond microfinance the VMSS way Beyond Microfinance. Indian J. Soc. Work 2015, 71, 551-576.

35. Kar, A.K. Income Smoothing, Capital Management and Provisioning Behaviour of Microfinance Institutions: A Study Using Global Panel Data. Eur. J. Dev. Res. 2017, 29, 108-126. [CrossRef]

36. Geissler, K.H.; Leatherman, S. Providing primary health care through integrated microfinance and health services in Latin America. Soc. Sci. Med. 2015, 132, 30-37. [CrossRef]

37. Siwale, J. Why Did I Not Prepare for This? The Politics of Negotiating Fieldwork Access, Identity, and Methodology in Researching Microfinance Institutions. Sage Open 2015, 5, 2158244015587560. [CrossRef]

38. D'Espallier, B.; Hudon, M.; Szafarz, A. Unsubsidized microfinance institutions. Econ. Lett. 2013, 120, $174-176$. [CrossRef]

39. Mahmud, A.U.; Tulla, A.F. Geography of rural enterprise banking and microfinance institutions in bangladesh. Doc. d'Analisi Geogr. 2015, 61, 325-350. [CrossRef]

40. Wulandari, P.; Kassim, S.; Adhi Kasari Sulung, L.; Iwani Surya Putri, N. Unique aspects of the Islamic microfinance financing process: Experience of Baitul Maal Wa Tamwil in Indonesia. Humanomics 2016, 32, 230-247. [CrossRef]

41. Burzynska, K.; Berggren, O. The Impact of Social Beliefs on Microfinance Performance. J. Int. Dev. 2015, 27, 1074-1097. [CrossRef]

42. Goodman, R. Borrowing Money, Exchanging Relationships: Making Microfinance Fit into Local Lives in Kumaon, India. World Dev. 2017, 93, 362-373. [CrossRef]

43. Saha, S. Expanding health coverage in India: Role of microfinance-based self-help groups. Glob. Health Action 2017, 10, 1321272. [CrossRef]

44. Ojha, S.; Szatkowski, L.; Sinha, R.; Yaron, G.; Fogarty, A.; Allen, S.; Smyth, A.R.; Choudhary, S. Feasibility and pilot study of the effects of microfinance on mortality and nutrition in children under five amongst the very poor in india: Study protocol for a cluster randomized controlled trial. Trials 2014, 15, 298. [CrossRef]

45. Antoniello, P. Banking the Unbanked: Women and Microfinance in India. Urbanities 2015, 5, 63-71.

46. Sahu, G.B. How Effective is a Self-Help Group Led Microfinance Programme in Empowering Women? Evidence from Rural India. J. Asian Afr. Stud. 2015, 50, 542-558. [CrossRef] 
47. Atmadja, A.S.; Su, J.J.; Sharma, P. Examining the impact of microfinance on microenterprise performance (implications for women-owned microenterprises in Indonesia). Int. J. Soc. Econ. 2016, 43, 962-981. [CrossRef]

48. Baptista, J.A.G.; Ramalho, J.J.S.; Vidigal da Silva, J. Understanding the microenterprise sector to design a tailor-made microfinance policy for Cape Verde. Port. Econ. J. 2006, 5, 225-241. [CrossRef]

49. Zhang, Q.; Posso, A. Microfinance and gender inequality: Cross-country evidence. Appl. Econ. Lett. 2017, 24, 1494-1498. [CrossRef]

50. Guo, L.; Jo, H. Microfinance Interest Rate Puzzle: Price Rationing or Panic Pricing? Asia-Pac. J. Financ. Stud. 2017, 46, 185-220. [CrossRef]

51. Jan, S.; Ferrari, G.; Watts, C.H.; Hargreaves, J.R.; Kim, J.C.; Phetla, G.; Pronyk, P.M. Economic evaluation of a combined microfinance and gender training intervention for the prevention of intimate partner violence in rural South Africa. Health Policy Plan. 2011, 26, 366-372. [CrossRef] [PubMed]

52. Mazumder, M.S.U. Role of Microfinance in Sustainable Development in Rural Bangladesh. Sustain. Dev. 2015, 23, 396-413. [CrossRef]

53. Minani, I. Impact of Microfinance and Entrepreneurship on Poverty Alleviation: Does National Culture Matter? Eur. J. Bus. Manag. 2015, 5, 35-42.

54. Hofstede, G. Culture's Consequences: Comparing Values, Behaviors, Institutions, and Organizations Across Nations, 2nd ed.; SAGE Publications: Thousand Oaks, CA, USA, 2001.

55. Holsti, O.R. Content Analysis for the Social Sciences and Humanities; Addison-Wesley (content analysis): Reading, MA, USA, 1969.

56. Berelson, B. Content Analysis in Communication Research; American Psychological Association: Washington, DC, USA, 2000.

57. Krippendorff, K. Content Analysis: An. Introduction to its Methodology; SAGE Publications Ltd.: Thousand Oaks, CA, USA, 2018.

58. Cull, R.; Demirgüç-Kunt, A.; Morduch, J. Does Regulatory Supervision Curtail Microfinance Profitability and Outreach? World Dev. 2011, 39, 949-965. [CrossRef]

59. Tchakoute-Tchuigoua, H. Is there a difference in performance by the legal status of microfinance institutions? Q. Rev. Econ. Financ. 2010, 50, 436-442. [CrossRef]

60. Gertler, P.; Levine, D.I.; Moretti, E. Do microfinance programs help families insure consumption against illness? Health Econ. 2009, 18, 257-273. [CrossRef]

61. Ashta, A.; Khan, S.; Otto, P. Does Microfinance cause or reduce suicides? Policy recommedations for reducing borrowers stress. Strateg. Chang. 2015, 24, 165-190. [CrossRef]

62. Kruskal, W.H.; Wallis, W.A. Use of Ranks in One-Criterion Variance Analysis. J. Am. Stat. Assoc. 1952, 47, 583-621. [CrossRef]

63. Holvoet, N. The Impact of Microfinance on Decision-Making. Dev. Chang. 2005, 36, 75-102. [CrossRef]

64. Rai, A. Indian Microfinance Institutions: Performance of Young and Old Institutions. Vis. J. Bus. Perspect. 2015, 19, 189-199. [CrossRef]

65. Lozano, R. Towards better embedding sustainability into companies' systems: An analysis of voluntary corporate initiatives. J. Clean. Prod. 2012, 25, 14-26. [CrossRef]

66. Amersdorffer, F.; Buchenrieder, G.; Bokusheva, R.; Wolz, A. Efficiency in microfinance: Financial and social performance of agricultural credit cooperatives in Bulgaria. J. Oper. Res. Soc. 2015, 66, 57-65. [CrossRef]

67. Pelka, N.; Musshoff, O.; Weber, R. Does weather matter? How rainfall affects credit risk in agricultural microfinance. Agric. Financ. Rev. 2015, 75, 194-212. [CrossRef]

68. Cheng, E.; Ahmed, A.D. The demand for credit, credit rationing and the role of microfinance: Evidence from poor rural counties of China. China Agric. Econ. Rev. 2014, 6, 295-315. [CrossRef]

69. Kebede, H.A.; Berhanu, W. How efficient are the ethiopian microfinance institutions in extending financial services to the poor? A comparison with the commercial Banks. Qual. Quant. 2015, 51, 112-135. [CrossRef]

70. Hadi, R.; Wahyudin, U.; Ardiwinata, J.S.; Abdu, W.J. Education and microfinance: An alternative approach to the empowerment of the poor people in Indonesia. Springerplus 2015, 4, 244. [CrossRef]

71. Qamar, M.A.J.; Masood, S.; Nasir, M. Impact of microfinance on the non-monetary aspects of poverty: Evidence from Pakistan. Qual. Quant. 2017, 51, 891-902. [CrossRef]

72. Lønborg, J.H.; Rasmussen, O.D. Can. Microfinance Reach the Poorest: Evidence from a Community-Managed Microfinance Intervention. World Dev. 2014, 64, 460-472. [CrossRef] 
73. Nasrin, S.; Baskaran, A.; Rasiah, R. Microfinance and savings among the poor: Evidence from Bangladesh microfinance sector. Qual. Quant. 2017, 51, 1435-1448. [CrossRef]

74. Voola, A. Gendered poverty and education: Moving beyond access to expanding freedoms through microfinance policy in India and Australia. Int. Educ. J. 2016, 15, 84-104.

75. Nawaz, F. Microfinance, Financial Literacy, and Household Power Configuration in Rural Bangladesh: An Empirical Study on Some Credit Borrowers. Voluntas 2015, 26, 1100-1121. [CrossRef]

76. Spiegel, S.J. Microfinance services, poverty and artisanial mineworkers in Africa: In search of measures for empowering vulnerable groups. J. Int. Dev. 2012, 24, 485-517. [CrossRef]

77. Akpalu, W.; Alnaa, S.E.; Aglobitse, P.B. Access to microfinance and intra household business decision making: Implication for efficiency of female owned enterprises in Ghana. J. Socio. Econ. 2012, 41, 513-518. [CrossRef]

78. Zulfiqar, G. Does Microfinance Enhance Gender Equity in Access to Finance? Evidence from Pakistan. Fem. Econ. 2017, 23, 160-185. [CrossRef]

79. Agbola, F.W.; Acupan, A.; Mahmood, A. Does microfinance reduce poverty? New evidence from Northeastern Mindanao, the Philippines. J. Rural Stud. 2017, 50, 159-171. [CrossRef]

80. Meador, J.; Fritz, A. Food security in rural Uganda: Assessing latent effects of microfinance on pre-participation. Dev. Pract. 2017, 27, 340-353. [CrossRef]

81. Ostrove, M. A tale of three cities. Am. City Cty. 2017, 132, 8-10.

82. Jia, X.; Xiang, C.; Huang, J. Microfinance, self-employment, and entrepreneurs in less developed areas of rural china. China Econ. Rev. 2013, 27, 94-103. [CrossRef]

83. Taylor, M. Freedom from poverty is not for free': Rural development and the microfinance crisis in Andhra Pradesh, India. J. Agrar. Chang. 2011, 11, 484-504. [CrossRef]

84. Taylor, M. The antinomies of 'financial inclusion': Debt, distress and the workings of indian microfinance. J. Agrar. Chang. 2012, 12, 601-610. [CrossRef]

85. Bond, P. Debt, Uneven Development and Capitalist Crisis in South Africa. Backgr. Pap. Rosa Luxembg. Stift. Work. 2012, 2, 1-25.

86. Thrikawala, S.; Locke, S.; Reddy, K. Board structure-performance relationship in microfinance institutions (MFIs) in an emerging economy. Corp. Gov. 2016, 16, 815-830. [CrossRef]

87. Bassem, B.S. Governance and performance of microfinance institutions in Mediterranean countries. J. Bus. Econ. Manag. 2009, 10, 31-43. [CrossRef]

88. DeLoach, S.B.; Lamanna, E. Measuring the Impact of Microfinance on Child Health Outcomes in Indonesia. World Dev. 2011, 39, 1808-1819. [CrossRef]

89. Holland, T.; Wang, L. Avoiding the perils and fulfilling the promises of microfinance: A closer examination of the educational outcomes of clients' children in Nicaragua. Int. J. Educ. Dev. 2011, 31, 149-161. [CrossRef]

90. Tseng, Y.H.; Khan, M.A. Where do the poorest go to seek outpatient care in Bangladesh: Hospitals run by government or microfinance institutions? PLoS ONE 2015, 10, e0121733. [CrossRef]

91. Ghalib, A.K. How effective is microfinance in reaching the poorest? Empirical evidence on programme outreach in rural Pakistan. J. Bus. Econ. Manag. 2013, 14, 467-480. [CrossRef]

92. Bali, R.; Yang, F. The impact of microfinance on factors empowering women: Regional and Delivery Mechanisms in India's SHG Programme. J. Dev. Studies 2016, 53, 684-699. [CrossRef]

93. Geissler, K.H.; Goldberg, J.; Leatherman, S. Using microfinance to facilitate household investment in sanitation in rural Cambodia. Health Policy Plan. 2016, 31, 1193-1199. [CrossRef] [PubMed]

94. Taylor, M.; Moser, R.M.B.; Gonzalez, L. Microfinance and climate change impacts: The case of agroamigo in Brazil. RAE Rev. Adm. Empres. 2015, 55, 397-407.

95. Mobin, M.A.; Masih, M.; Alhabshi, S.O. Religion of Islam and Microfinance: Does It Make Any Difference? Emerg. Mark. Financ. Trade 2017, 53, 1547-1562. [CrossRef]

96. Adnan, M.; AAjija, S.R. The effectiveness of baitul maal wat tamwil in reducing poverty the case of indonesian islamic microfinance institution. Humanomics 2015, 31, 160-182. [CrossRef]

97. Dalan, G.R.E.; Srnec, K. The scenario of microfinance in Latin America against the international financial crisis. Agric. Econ. 2018, 56, 583-590. [CrossRef]

98. Vogelgesang, U. Microfinance in times of crisis: The effects of competition, rising indebtedness, and economic crisis on repayment behavior. World Dev. 2003, 31, 2085-2114. [CrossRef]

99. Atkinson, J.; De Janvry, A.; McIntosh, C.; Sadoulet, E. Prompting microfinance borrowers to save: A field experiment from Guatemala. Econ. Dev. Cult. Chang. 2013, 62, 21-64. [CrossRef] 
100. Budiman, I.; Takama, T.; Pratiwi, L.; Soeprastowo, E. Role of microfinance to support agricultural climate change adaptations in Indonesia: Encouraging private sector participation in climate finance. Futur. Food J. Food Agric. Soc. 2016, 4, 55-68.

101. Fenton, A.; Paavola, J.; Tallontire, A. The Role of Microfinance in Household Livelihood Adaptation in Satkhira District, Southwest Bangladesh. World Dev. 2017, 92, 192-202. [CrossRef]

102. Shoji, M. Evaluation of contingent repayments in microfinance: Evidence from a natural disaster in bangladesh. Dev. Econ. 2012, 50, 116-140. [CrossRef]

103. Stark, L.; Kassim, N.; Sparling, T.; Buscher, D.; Yu, G.; Boothby, N. Assessing the impact of microfinance programming on children: An evaluation from post-tsunami Aceh. Disasters 2015, 39, 295-315. [CrossRef] [PubMed]

104. Becchetti, L.; Castriota, S. Does Microfinance Work as a Recovery Tool After Disasters? Evidence from the 2004 Tsunami. World Dev. 2011, 39, 898-912. [CrossRef]

105. Poston, A. Lessons from a microfinance recapitalisation programme. Disasters 2010, 34, 328-336. [CrossRef] [PubMed]

106. Azim, M.I.; Sheng, K.; Barut, M. Combating corruption in a microfinance institution. Manag. Audit. J. 2017, 32, 445-462. [CrossRef]

107. Akanga, F.K. Microfinance accountability in Cameroon: A cure or a curse for poverty alleviation? J. Account. Organ. Chang. 2017, 13, 112-130. [CrossRef]

108. Marini, L.; Andrew, J.; van der Laan, S. Tools of accountability: Protecting microfinance clients in South Africa? Account. Audit. Account. J. 2017, 30, 1344-1369. [CrossRef]

109. Okoye, N.; Siwale, J. Microfinance regulation and effective corporate governance in Nigeria and Zambia. Int. J. Law Manag. 2017, 59, 102-121. [CrossRef]

110. Ayayi, A.G. Credit risk assessment in the microfinance industry: An application to a selected group of Vietnamese microfinance institutions and an extension to East Asian and Pacific microfinance institutions Ayayi Credit Risk Assessment. Econ. Transit. 2012, 20, 37-72. [CrossRef]

111. Cespedes, G.C.I.; Gonzalez, L.K.G. The financial vs. the social approach of microfinance. A comparative global analysis/El enfoque financiero vs. el enfoque social del microcredito. Un analisis comparativo mundial. REVESCO. Revista de Estudi. REVESCO. Rev. Estud. Coop. 2015, 118, 31-60. 